\title{
KONSEP ADMINISTRASI PENDIDIKAN
}

\author{
Nola nopita \\ Universitas Negeri Padang \\ Indonesia \\ E-mail : \\ nollanopita@gmail.com
}

\section{KONSEP ADMINISTRASI PENDIDIKAN}

\begin{abstract}
Abstrak
Administrasi merupakan usaha menciptakan kerja sama antara guru dan karyawan untuk mengefektifkan proses belajar-mengajar. Pembuatan artikel ini bertujuan agar dapat memberikan pengetahuan tentang administrasi pendidikan dalam bidang keguruan. Administrasi pendidikan juga merupakan segenap teknik dan prosedur yang digunakan dalam penyelenggaraan hubungan pendidikan sesuai dengan kebijakan yang telah ditetapkan guna untuk mencapai tujuan pendidikan. Dalam rangka operasionalisasi konsep administrasi pendidikan tersebut. Sekolah sebagai organisasi pendidikan harus mengelola tiga hal yakni material, SDM, dan Kurikulum
\end{abstract}

\section{a. Pengertian Administrasi}

Secara konseptual administrasi pendidikan terdiri dari dua kata yang masing-masing punya pengertian tersendiri yaitu administrasi dan pendidikan. Hal ini menunjukkan bahwa administrasi pendidikan adalah penerapan ilmu administrasi dalam dunia pembinaan, pengembangan dan pengendalian usaha dan praktek-praktek pendidikan. Oleh karena itu, sebelum menguraikan apakah administrasi pendidikan itu, ada baiknya kita mengetahui terlebih dahulu apakah yang dimaksud dengan administrasi.

Kata administrasi menurut Daryanto ( 2011 : 1 ) berasal dari bahasa latin "ad" dan "ministro". Ad mempunyai arti "kepada" dan ministro berarti "melayani”. Secara bebas dapat diartikan bahwa administrasi merupakan pelayanan dan pengabdian terhadap subjek tertentu.

Selanjutnya untuk mendapatkan gambaran yang lebih jelas tentang pengertian administrasi, berikut beberapa pengertian administrasi menurut para ahli : 1) Daryanto ( 2011:7) : adalah aktivitasaktivitas untuk mencapai suatu tujuan, atau proses penyelenggaraan kerja untuk mencapai suatu tujuan yang telah ditetapkan.

2) Trisna (dalam Daryanto, $2011: 7$ ) :

adalah keseluruhan proses penyelenggaraan dalam usaha kerja sama dua orang atau lebih dengan secara rasional untuk mencapai tujuan yang telah ditetapkan sebelumnya secara efisien.

3) Ngalim Purwanto ( $2010: 1):$ adalah suatu kegiatan atau usaha untuk membantu , melayani, mengarahkan, atau mengatur semua kegiatan di dalam mencapai suatu tujuan.

4) Syaiful Sagala ( $2009: 26$ ) : adalah rangkaian kegiatan bersama sekelompok manusia seacara sistematis untuk 


\section{KONSEP ADMINISTRASI PENDIDIKAN}

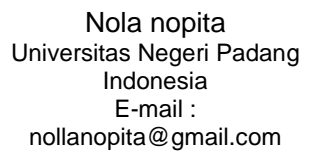

menjalankan roda suatu usaha atau misi organisasi agar dapat terlaksana, suatu usaha dengan suatu tujuan tertentu yang telah ditetapkan.

Berdasarkan pengertian administrasi tersebut, maka dalam setiap kegiatan administrasi terdapat beberapa unsur yang selalu kait-mengait satu sama lain. Unsur pokok di dalam administrasi yang dimaksud adalah :

- Adanya sekelompok manusia yang tergabung dalam satu organisasi

- $\quad$ Proses yang dilakukan dalam rangka mencapai tujuan yang telah ditetapkan

- Adanya sumber daya dan sumber dana

- Rangkaian kegiatan atau adanya proses

- Proses dilakukan secara efektif dan efisien

\section{Dengan mengemukakan unsur-unsur} tersebut di atas dapat ditarik kesimpulan bahwa pengertian administrasi adalah suatu proses kerja sama antara orang-orang dengan menggunakan sumber dana dan sumber daya yang ada untuk mencapai tujuan yang telah ditetapkan secara efektif dan efisien.

\section{b. Pengertian Pendidikan}

Pendidikan diartikan oleh beberapa tokoh pendidikan sebagai berikut :

1) Suparlan Suhartono ( $2009: 80$ ): merupakan system proses perubahan menuju pendewasaan, pencerdasan, dan pematangan diri.

2) Chalijah Hasan ( $1989: 19):$ adalah bantuan yang diberikan dengan sengaja kepada anak dalam pertumbuhan jasmani dan rohaninya untuk mencapai tingkat dewasa.

3) Ahmad D Marimba ( $1989: 19$ ) adalah bimbingan dan pimpinan secara sadar oleh si pendidik terhadap perkembangan jasmani dan rohani si terdidik menuju terbentuknya kepribadian yang utama.

4) Abdurrahman An-Nahlawi (dalam Daryanto, $2011: 5$ ) adalah proses yang mempunyai tujuan sasaran dan objek.

Dari pengertian yang dikemukakan oleh para ahli di atas maka dapat diambil kesimpulan bahwa pendidikan merupakan : 


\title{
KONSEP ADMINISTRASI PENDIDIKAN
}

\author{
Nola nopita \\ Universitas Negeri Padang \\ Indonesia \\ E-mail : \\ nollanopita@gmail.com
}

- Suatu usaha pembentukan kepribadian dan kemampuan anak dalam menuju kedewasaan

- Suatu bimbingan yang diberikan kepada anak dalam pertumbuhannya

- Suatu usaha dalam mencapai tujuan

Setelah melihat pengertian administrasi dan pendidikan, maka nampak jelas bahwa pendidikan dapat berjalan dengan baik dalam pencapaian tujuan diperlukan administrasi untuk mengatur atau mengelola kerja sama secara sistematis melalui tahapan-tahapan secara terpadu. Maka semakin jelas pentingnya administrasi bagi kehidupan manusia termasuk dalam bidang pendidikan

\section{c. Pengertian Administrasi Pendidikan}

Untuk memperluas pemahaman tentang pengertian administrasi pendidikan berikut ini dikemukakan beberapa batasan atau definisi yaitu :

1) Ngalim Purwanto ( $2010: 4)$ : Administrasi pendidikan adalah segenap proses pengerahan dan pengintegrasian segala sesutu, baik personal, spiritual maupun material, yang bersangkut paut dengan pencapaian tujuan pendidikan. 2) Daryanto ( $2011: 12$ ) : Administrasi pendidikan adalah tindakan mengkoordinasikan perilaku manusia dalam pendidikan agar sumber daya yang ada dapat ditata sebaik mungkin sehingga tujuan pendidikan dapat tercapai secara produktif.

3) Syaiful Sagala ( $2009: 39)$ :

Administrasi pendidikan adalah suatu proses atau peristiwa mengkoordinasikan sejumlah kegiatan yang saling bergantung dari orangorang dan kelompok-kelompok baik kegiatan yang berada pada pemerintahan maupun satuan pendidikan dalam mencapai tujuan pendidikan.

4) Dadang Suhardan $(2010: 30)$ :

Administrasi pendidikan adalah disiplin ilmu yang mempelajari usaha kerja sama dengan melibatkan segenap sumber daya yang ada untuk mengembangkan potensi peserta didik dalam mencapai tujuan pendidikan secara efektif dan efisien.

5) Djam'an Satori ( dalam Uhar

Suharsaputra, $2010: 12$ ) : administrasi pendidikan dapat diartikan sebagai keseluruhan proses kerja sama dengan 


\section{KONSEP ADMINISTRASI PENDIDIKAN}

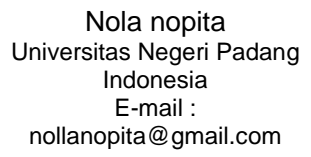

memanfaatkan semua sumber personil dan

perlu dimiliki, untuk menunjang efektifitas

materil yang tersedia dan sesuai untuk mencapai tujuan pendidikan yang telah ditetapkan secara efektif dan efisien.

dan efisiensi tugasnya atau pimpinan sekolah, dengan memahami kebutuhankebutuhan sekolah yang harus disediakan oleh pemerintah, penyelenggara program

Dengan memperhatikan berbagai definisi di atas, dapat disimpulkan bahwa administrasi pendidikan adalah suatu proses kerja sama oleh sejumlah orang yang memanfaatkan semua sumber dan fasilitas yang ada untuk mencapai tujuan pendidikan yang telah ditetapkan secara efektif dan efisien.

\section{TUJUAN KAJIAN ADMINISTRASI PENDIDIKAN}

Tujuan kajian administrasi pendidikan dapat ditegaskan oleh beberapa ahli diantaranya :

1) Syaiful Sagala ( $2009: 45$ ) : adalah menyediakan dasar konseptual dengan mendefinisikan administrasi dengan mengimplementasikannya dalam kegiatan pendidikan/untuk membentuk pemahaman dan memiliki keterampilan dalam bidang administrasi pendidikan. Keterampilan ini sekolah, dan bagaimana sekolah itu dikelola sampai pada batas kualitas yang ditentukan.

2) Daryanto ( $2011: 17$ ) : adalah agar semua kegiatan itu mendukung tercapainya tujuan pendidikan atau dengan kata lain administrasi digunakan di dalam dunia pendidikan adalah agar tujuan pendidikan tercapai. Apabila administrasi pendidikan ini semakin baik, semakin yakin pula tujuan pendididkan itu akan tercapai dengan baik.

3) Sergiovanni dan Carvar ( dalam Daryanto, 2011 : 17 ) : ada 4 tujuan administrasi, yaitu : efektivitas produksi, efisisensi, kemampuan menyesuaikan diri ( adaptiveness ), dan kepuasan kerja. Keempaat tujuan tersebut menentukan keberhasilan suatu penyelenggara sekolah.

Berdasarkan rumusan administrasi pendidikan dan tujuan kajian administrasi pendidikan yang telah dijelaskan di atas, dapat disimpulkan bahwa tujuan dari kajian 


\section{KONSEP ADMINISTRASI PENDIDIKAN}

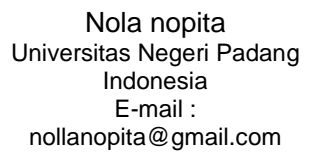

administrasi pendidikan adalah agar semua kegiatan mendukung tercapainya tujuan pendidikan dengan kata lain administrasi yang digunakan dalam dunia pendidikan diusahakan untuk mencapai tujuan pendidikan. Dalam hal ini administrasi pendidikan memberikan keterampilan dan pengetahuan kepada pimpinan sekolah dalam melaksanakan kepemimpinan sekolah agar tujuan pendidikan yang telah ditetapkan bersama dapat tercapai secara efektif dan efisien. Tanpa adanya administrasi dan kepemimpinan yang baik, sulit kiranya bagi sekolah untuk berjalan lancar menuju ke arah tujuan pendidikan dan pengajaran yang seharusnya dicapai sekolah.

Semua kegiatan sekolah akan dapat berjalan lancar dan berhasil baik jika pelaksanaannya melalui proses-proses yang menuruti garis fungsi-fungsi administrasi pendidikan. Menurut Ngalim Purwanto (2010 : 14 ) fungsi-fungsi administrasi tersebut adalah :

1) Perencanaan (planning) Perencanaan adalah aktivitas memikirkan dan memilih rangkaian tindakan-tindakan yang tertuju pada tercapainya maksudmaksud dan tujuan pendidikan

2) Pengorganisasian (organizing)

Organisasi adalah aktivitas-aktivitas menyusun dan membentuk hubunganhubungan sehingga terwujudlah kesatuan usaha dalam mencapai maksud-maksud dan tujuan-tujuan pendidikan

3) Pengoordinasian (coordinating)

Koordinasi adalah aktivitas membawa orang-orang material, pikiran-pikiran, teknik-teknik dan tujuan-tujuan ke dalam hubungan yang harmonis dan produktif dalam mencapai tujuan

4) Komunikasi

Komunikasi adalah setiap bentuknya adalah suatu proses yang hendak mempengaruhi sikap dan perbuatan orang-orang dalam struktur organisasi

5) Supervisi

Supervisi sebagai fungsi administrasi pendidikan berarti aktivitas-aktivitas untuk menentukan kondisi-kondisi yang esensial yang akan menkamin tercapainya tujuantujuan pendidikan

6) Kepegawaian 


\title{
KONSEP ADMINISTRASI PENDIDIKAN
}

\author{
Nola nopita \\ Universitas Negeri Padang \\ Indonesia \\ E-mail : \\ nollanopita@gmail.com
}

Kepegawaian yang menjadi titik penekanan

ialah persona itu sendiri, aktivitas yang

dilakukan di dalam kepegawaian antara lain

menempatkan dan membimbing personel

7) Pembiayaan (budgeting)

Pembiayaan harus sudah dipikirkan sejak

pembuatan planning sampai dengan

pelaksanaannya

8) Penilaian (evaluating)

Evaluasi adalah aktivitas untuk meneliti sampai dimana pelaksanaan yang dilakukan

di dalam proses keseluruhan organisasi

mencapai hasil sesuai dengan program yang

telah ditetapkan dalam rangka mencapai

tujuan pendidikan

Fungsi-fungsi pokok tersebut satu sama lain sangat erat hubungannya, dan semuanya merupakan suatu proses keseluruhan yang tidak terpisahkan satu sama lain.

Dengan pemahaman sebagaimana dikemukakan di atas, nampak bahwa satu fungsi penting dari adminitrasi pendidikan adalah berkaitan dengan proses pembelajaran yaitu mulai dari persiapan sampai evaluasi untuk melihat kualitas dari suatu proses tersebut, dalam hal ini sekolah merupakan sebuah lembaga pendidikan yang melakukan proses pembelajaran terutama guru perlu mengelola kegiatan tersebut dengan baik agar tujuan pendidikan tercapai.

\section{B. FUNGSI-FUNGSI ADMINISTRASI PENDIDIKAN}

\section{Perencanaan}

Proses perencanaan pada umumnya menyangkut peramalan dan pengambilan keputusan. Melalui peramal kita memperkirakan apa yang akan terjadi di masa datang berdasarkan apa yang terjadi di masa datang berdasarkan informasi yang diperoleh dari masa lalu dan masa kini. Semakin lengkap data yang diperoleh dan digunakan, dan semakin tepat penafsiran terhadap data tersebut, semakin besar peluang bagi ketepatan ramalan kita.

Perencanaan dapat diartikan sebagai penentuan langkah-langkah yang akan dilaksanakan di masa datang dalam rangka mencapai tujuan yang diingin kan. Oleh karena itu perencanaan melibatkan kegiatan pengambilan keputusan dari sejumlah alternatif. 


\section{KONSEP ADMINISTRASI PENDIDIKAN}

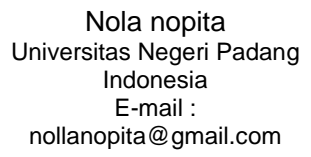

Informasi mengenai keadaan masa lampau dan sekarang perlu dihimpun secara tepat, lengkap, dan dapat dipercaya. Berdasarkan informasi ini kita mengadakan taksiran tentang kondisi sekarang atau prediksi di masa depan. Berdasarkan taksiran inilah kita mengemukakan sejumlah alternatif tindakan. Dan dari antara alternatif-alternatif ini kita mengambil salah satu yang paling menguntungkan. Inilah keputusan yang kita ambil, dan yang akan dilaksanakan. Demikian kita lihat bahwa perencanaan selalu berorientasi ke depan (future oriented).

Dalam rangka melakukan perencanaan pendidikan, prinsip-prinsip berikut perlu diperhatikan. a. Perencanaan adalah suatu proses yang berkesinambungan.

b. Perencanaan adalah suatu proses yang komprehensif.

c. Perencanaan hendaklah menghasilkan rencana yang fleksibel dan realistis.

d. Perencanaan harus berorientasi pada tujuan. e. Perencanaan pendidikan harus memperhitungkan aspek-aspek kuantitatif dan kualitatif pendidikan.

f. Perencanaan pendidikan harus melahirkan rangkaian tindakan yang jelas, terarah, dan menurut prinsip efisiensi dan efektifitas.

g. Perencanaan pendidikan harus didasarkan pada identifikasi fenomena pendidikan yang sedang terjadi.

\section{Pengorganisasian}

Pada dasarnya, fungsi pengorganisasi berkenaan dengan upaya mengembangkan mata rantai hubungan-hubungan kerja (formal) dan pembagian di dalam organisasi atau lembaga. Untuk mencapai maksud ini pengorganisasian melibatkan usaha identifikasi tugas-tugas tersebut yang akan dilaksanakan, mengelompokkan tugas-tugas sehingga merupakan satuan-satuan, dan menetapkan wewenang yang diperlukan.

Secara umum dapat dikatakan, melalui pengorganisasian dicoba 


\title{
KONSEP ADMINISTRASI PENDIDIKAN
}

\author{
Nola nopita \\ Universitas Negeri Padang \\ Indonesia \\ E-mail : \\ nollanopita@gmail.com
}

mempertemukan pekerja tertentu dengan pekerjaan dan fasilitas kerja yang spesifik. Di lingkungan sekolah, umpamanya, setiap guru mendapat tugas yang jelas serta wewenang yang sepadan. Dia harus mengetahui fasilitas belajar-mengajar yang perlu dan dapat digunakannya.

Menurut Blau, setiap organisasi formal mengandung ciri-ciri pembagian kerja yang jelas, hierarki wewnang dan tanggung jawab, sistem aturan dan kebijakan, interaksi yang bersifat nonpribadi, penugasan yang didasarkan pada kualifikasi teknis, dan efisiensi secara teknis.

Namun demikian di lingkungan lembaga pendidikan pengembangan hubungan-hubungan antar pribadi khususnya dengan siswa mutlak perlu. Kita ketahui bahwa dengan hubungan antar pribadi khususnya dengan siswa mutlak perlu. Kita ketahui bahwa dengan hubungan formal saja interaksi akan sangat terbatas dan berlangsung kaku, dan jarak sosial terlalu besar.

\section{Perangsangan}

Untuk maksud yang sama dengan perangsangan (stimulasting), sering juga digunakan istilah pendorongan (motivating), pengaktifan, pengarahan dan lainlain.Perangsangan dilakukan dengan maksud agar para pekerja melaksanakan tugastugasnya dengan menggunakan kemampuannya semaksimal-maksimalnya.

Tidak ada resep perangsangan yang dapat digunakan dengan berhasil dalam setiap situasi. Namun demikian pedoman umum yang dapat digunakan adalah :

a. Motivasi kepada anak didik, bawahan, pegawai, dan sebagainya

b. Komunikasi yang efektif

c. Mengembangkan partisipasi aktif dikalangan pekerja.

d. Pemberian tugas yang sesuai dengan minat dan kemampuan pekerja

e. Perbaikan iklim organisasi dan kondisikondisi pekerja.

\section{Pengkoordinasian}

Koordinasi berarti sinkronisasi kegiatan-kegiatan ke arah pencapaian 


\title{
KONSEP ADMINISTRASI PENDIDIKAN
}

\author{
Nola nopita \\ Universitas Negeri Padang \\ Indonesia \\ E-mail : \\ nollanopita@gmail.com
}

tujuan-tujuan. Jika semua pekerja mendapat hak untuk melaksanakan pekerjaan dengan cara yang dikehendaki masing-masing, maka setiap orang dari mereka biasanya dituntun oleh pikiran dan gagasan sendirisendiri mengenai apa yang diperbuatnya dan bagaimana akan dilakukannya.

Menurut Newport, koordinasi merupakan alat untuk mengkonsentrasi-kan dan menggunakan usaha-usaha kooperatif untuk melaksanakan tugas-tugas dengan cara-cara yang efektif dan ekonomis. Dengan koordinasi yang efektif para pekerja tidak akan melaksanakan pekerjaannya masing-masing tanpa memperhatikan akibat-akibatnya terhadap pekerjaan dan bagian lain serta terhadap pekerjaan sebagai suatu keseluruhan. Dengan koordinasi pekerjaan akan dimulai dan diselesaikan tepat pada waktunya.

\section{Penilaian}

Di dalam fungsi penilaian ini terlihat kegiatan-kegiatan monitoring, kontrol, dan supervisi. Monitoring dilakukan selama berlangsung proses pelaksanaan pekerjaannya untuk memperoleh informasi tentang pelaksanaan.

Demikian kita lihat bahwa penilaian, monitoring, kontrol dan supervisi berkaitan sangat erat dan mempunyai tujuan yang sama ialah untuk lebih memperbaiki pelaksanaan program suatu organisasi atau lembaga.

Penilaian tidak hanya mengenai hasil atau tujuan akhir seperti telah direncanakan semula. Penilaian semacam ini dalam rangka sistim instruksional disebut evaluasi sumatif. Penilaian juga dilakukan selama berlangsungnya proses kegiatan penilaian ini disebut formative evaluation. Pendek kata, penilaian itu harus dilakukan secara berkesinambungan dan mengenai segi kehidupan organisasi atau lembaga.

\section{TUJUAN DAN MANFAAT}

\section{ADMINISTRASI PENDIDIKAN}

Tujuan administrasi pendidikan tidak lain adalah agar semua kegiatan itu mendukung tercapainya tujuan pendidikan atau dengan kata lain administrasi 


\section{KONSEP ADMINISTRASI PENDIDIKAN}

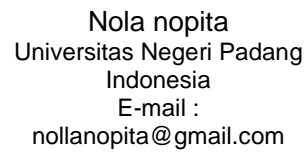

digunakan di dalam dunia pendidikan adalah agar tujuan pendidikan tercapai.

Seperti yang diutarakan Sergiovanni dan Carver (1975), ada empat tujuan administrasi, yaitu : efektivitas produksi, efisiensi, kemampuan menyesuaikan diri (adaptiveness), dan kepuasan kerja. Keempat tujuan tersebut dapat digunakan sebagai criteria untuk menentukan keberhasilan suatu penyelenggaraan sekolah.

Tujuan administrasi pendidikan di sekolah adalah mempersiapkan situasi di sekolah, agar pendidikan dan pengajaran berlangsung baik, sehingga tercapai tujuan khusus sekolah tersebut, yaitu :

1. Supaya anak-anak tamatan suatu sekolah memiliki pengetahuan dan pengertian dasar, mengenai hak dan kewajiban sebagai manusia pancasila sesuai dengan ketetapan MPRS No. IV / 1973 dan berbuat selaras dengan pengertian itu.

2. Supaya anak-anak tamatan suatu sekolah memiliki salah satu keterampilan atau kecakapan khusus, yang merupakan bekal untuk hidupnya dalam masyarakat.

3. Supaya anak-anak tamatan suatu sekolah memiliki dasar-dasar ilmu pengetahuan yang kokoh serta keterampilan untuk melanjutkan pendidikannya ke sekolah yang lebih tinggi.

Secara singkat, administrasi pendidikan di sekolah brtujuan menciptakan situasi yang memungkinkan anak mempunyai pengetahuan dasar yang kuat untuk melanjutkan pelajaran, mempunyai suatu kecakapan dan keterampilan khusus untuk dapat hidup sendiri dan dalam masyarakat, serta mempunyai sikap hidup sebagai manusia pancasila dengan pengabdian untuk pembangunan masyarakat pancasila Indonesia.

\section{RUANG LINGKUP ADMINISTRASI PENDIDIKAN}

Bidang-bidang yang tercakup dalam administrasi pendidikan adalah sangat banyak dan luas Yetapi yang sangat penting dan perlu diketahui oleh para kepala sekolah dan guru-guru pada umumnya ialah sebagai berikut:

\section{Bidang tata usaha sekolah, ini meliputi:}

1) Organisasi dan struktur pegawai tata usaha 


\section{KONSEP ADMINISTRASI PENDIDIKAN}

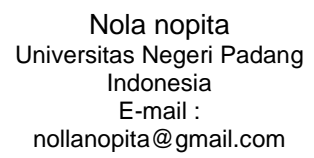

2) Anggaran belanja keuangan sekolah.

3) Masalah kepegawaian dan personalia sekolah.

4) Keuangan dan pembukuannya

5) Korespondensi / surat menyurat

6) Masalah pengangkatan, pemindahan, penempatan, laporan, pengisian buku induk, raport dan sebagainya

\section{Bidang personalia murid, yang meliputi} antara lain:

1) Organisasi murid

2) Masalah kesehatan murid

3) Masalah kesejahteraan murid

4) Evaluasi kemajuan murid

5) Bimbingan dan penyuluhan bagi murid

\section{Bidang personalia guru, meliputi antara} lain:

1) Pengangkatan dan penempatan tenaga guru

2) Organisasi personel guru

3) Masalah kepaegawaian

4) Masalah kondite dan evaluasi kemajuan guru

5) Refreshing dan up-grading guru-guru

\section{Bidang pengawasan (supervisi), yang} meliputi anatara lain:

1) Usaha membangkitkan semangat guru- guru dan pegawai tata usaha dalam menjalankan tugasnya masing-masing sebaik-baiknya.

2) Mengusahakan dan mengembangkan kerjasama yang baik antara guru, murid dan pegawai tata usaha sekolah.

3 Mengusahakan dan membuat pedoman cara-cara menilai hasil-hasil pendidikan dan pengajaran.

4) Usaha mempertinggi mutu dan pengalaman guru-guru pada umumnya.

\section{Bidang pelaksanaan dan pembinaan}

\section{kurikulum:}

1). Berpedoman dan mengetrapkan apa yang tercantum dalam kuriulum sekolah yang bersangkutan, dalam usaha mencapai dasardasar dan tujuan pendidikan

dan pengajaran.

2). Melaksanakan organisasi kurikulum beserta metode-metodenya, disesuaikan dengan pembaruan pandidikan dan lingkungan masyarakat. 